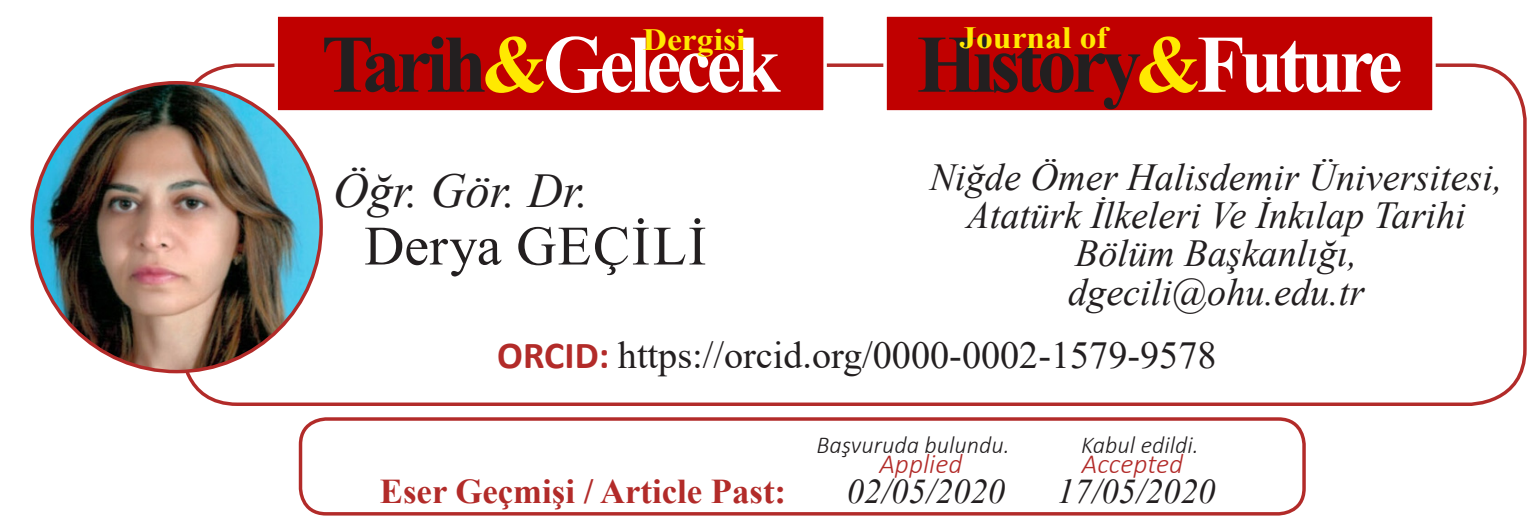

Araștırma Makalesi

DOI: http://dx.doi.org/10.21551/jhf.730916

Research Paper

Orjinal Makale / Orginal Paper

\title{
On Dokuzuncu Yüzyılda Osmanlı Donanmasında Yapılması Planlanan Islahat Hareketleri
}

\author{
Reformation Movements Planned to be Performed in the Ottoman \\ Navy in the Nineteenth Century
}

$\ddot{O} z$

On dokuzuncu yüzyllda Osmanlı Devleti'nde kaybedilen savaşlar sonucunda

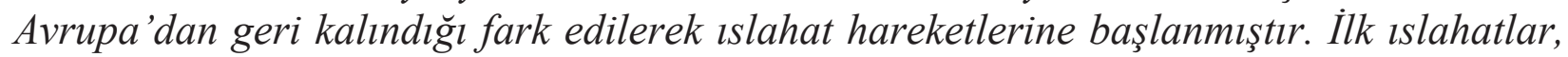
askeri alanda yapılarak en fazla önem verilen konu olmuştur. Çeşme ve Navarin faciaları ile Osmanlı Rus savaşlarl sonucunda ise deniz kuvvetlerinin iyi bir seviyeye getirilmesi için incelemeler yapılmıştır. Donanmada yapılmasına karar verilen ıslahatlar için uzmanlardan yararlanma yoluna gidilerek bir komisyon oluşturulmuştur. Bu komisyon tarafindan deniz kuvvetlerinin güçlendirilmesine dair çalışmalar yapılarak ıslahatlar hakkında bir rapor hazırlanmıştır. Komisyonun raporunda İstanbul ve Çanakkale boğazlarında bulunan kale ve istihkâmların tamiri, takviye edilmeleri ile sahillere torpidolar ve mayınlar yerleştirilmesi gibi bazı tedbirlerin alınması gerektiği bildirilmiştir. Ayrıca modern savaş gemileri satın alınarak bu gemileri kullanabilecek personelin yetiştirilmesinin öneminden bahsedilmiştir. Aşağılda komisyonun raporuna göre donanmanın güçlü bir hale getirilebilmesi için yapılması gereken ıslahat hareketleri anlatılmıştır.

Anahtar Kelimeler: Osmanl, Donanma, Yenilik, Plan.

\section{Abstract}

As a result of the wars lost in the Ottoman State during the nineteenth century, it was realized that the state was left behind Europe, and reformation movements were initiated. The first reformation movements were made in the military area as the most important issue. As a result of the defeats in Cesme and Navarin and the Ottoman Russian wars, investigations were carried out to bring the Navy to a good level. A commission was established to make 
use of the experts for the reformation movements to be carried out in the Navy. A report on reformation movements was prepared by this commission to strengthen the navy. The commission report said that some measures had to be taken, like repairing and reinforcing the fortresses in the Straits of Istanbul and Canakkale, and placing torpedoes and mines. In addition, the importance of purchasing modern warships and training the personnel who would use these ships was also mentioned in the report. The reformation movements that had to be performed according to the commission report, the reclamation actions that needed to be taken to make the Navy stronger are explained in the following parts.

Keywords: Ottoman, Navy, Innovation, Plan.

\section{Giriş}

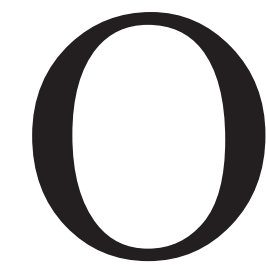

n sekizinci yüzyılın sonlarına doğru buhar makinesinin icadı, sanayi devrimi için önemli bir güç kaynağ 1 sağlamıştı. Bu hızlı gelişime bağlı olarak Avrupa'da önce buharlı gemiler daha sonra ise torpido ve zırhlı gemiler kullanılmaya başlamıştı. Avrupa'da başlayan bu yenilik hareketleri takip edilemediğinden Osmanlı Devleti denizlerdeki hâkimiyetini artık kaybetmişti. Özellikle 1770 Çeşme faciası Osmanlı denizciliğinde bir dönüm noktası olmuştur. Çeşme'de Türk deniz gücünün İngiliz amiral ve denizcilerinin yardımı ile Ruslar tarafından yakılması Türk denizciliğine 1571 İnebahtı deniz savaşından sonra vurulan ikinci bir darbedir. ' Çeşme faciası ile Osmanlı yöneticileri, denizciliğe önem vermenin gerektiğini anlamaya başlamıştır. Böylece, tersane ve donanma işlerinde reforma yönelerek modernizasyon çalışmaları hız kazanmıştır. Osmanlı Donanmasında ıslahat hareketlerinin önemli olduğunu kanıtlayan bir diğer konu da Navarin Olayıdır. Rusya, İngiltere ve Fransa 1827'de Londra'da aralarında bir anlaşma yaptılar. Bu anlaşmanın esası Yunanistan'a muhtariyet vermek ve Türklerin Mora'dan çıkmasını sağlamaktır. Bu sırada Osmanl1-Mısır Donanması Mora Yarımadası'nın güneyindeki Navarin Limanı'ndaydı. 20 Ekim 1827 sabahı İngiliz, Rus ve Fransız filoları Osmanl1-Mısır Donanması'na saldırdılar, bu baskında Osmanlı Devleti 6.000 asker kaybetti. 64 parçalık ${ }^{3}$ Osmanlı-Mısır Donanması'nın tamamen tahrip edilmesi ile sonuçlanan Navarin Olayı'nın Türk denizcilik tarihinde önemli bir yeri vardır. Çünkü bu baskınla büyük fedakârlıklarla meydana getirilmiş olan Osmanlı deniz gücü yok edilmişti. Navarin Olayı, Osmanlı Devleti'ni donanmasız bırakmakla kalmamış, denize elverişli ve tecrübe sahibi subay ve gemicileri, yarı teknik personeli de beraberinde yok etmişti. Osmanlı Devleti bu büyük felaketin ardından özellikle Karadeniz'de Rus Donanması'na karşı çıkacak güçte yeni bir donanma vücuda getirmek için büyük uğraşılar vermek zorunda kalmıştı. ${ }^{4}$ II. Mahmud, Navarin Olayı'nın ardından donanmanın geliştirilmesi için yeni bir program yapılmasını emretmişti. Böylece 1827-

1 Ali İhsan Gencer, Türk Denizcilik Tarihi Araştırmalarl, Türkiye Denizciler Sendikası Eğitim Dizisi 2, İstanbul 1986.

2 Nejat Gülen, Şanlı Bahriye, Türk Bahriyesinin İki Yüz Yıllık Tarihçesi, 1773-1973, İstanbul 2001, s. 56.

3 Fahir Armaoğlu, 19.Yüzyll Siyasi Tarih (1789-1914), Türk Tarih Kurumu Yayınları, Ankara 1997, s. 180.

4 Besim Özcan, Sinop Deniz Felaketi, 30 Kasım 1853, İstanbul 2008, s. 43. 
1834 y1lları arasında İstanbul'la birlikte Gemlik, İzmit ve Sinop gibi taşra tersanelerinde de harp gemileri inşasına başlanmışt1. ${ }^{5}$ Avrupa usullerine uygun yeni sistem savaş gemileri inşa edilerek Türk savaş filoları yeni baştan meydana getirilmeye çalışılmıştı. ${ }^{6}$

Osmanlı Devleti'nin kaderini belirleyecek kadar önemli savaşlardan biri de 18771878 Osmanlı Rus Savaşıdır. Rusya, çok fazla silah ve askerle Osmanlı ordusu savunma hazırlıklarını tamamlamadan saldırıya geçmişti. ${ }^{7}$ Osmanlı Rus Savaşı sırasında kara ve deniz kuvvetlerinin yaşadığı büyük kayıplar, askeri alanda gerilemeye başlandığını açıkça ortaya koymuştur. ${ }^{8}$ Osmanlı Rus Savaşı sonunda askeri alanda düzenin bozulduğunun fark edilmesi üzerine yeniden islahat hareketlerine ihtiyaç duyulmuştur. ${ }^{9}$ Osmanlı Donanmasında 1slahat hareketleri için bir komisyon oluşturularak incelemeler yapılmış ve rapor hazırlanmıştır. Bu rapora göre, İstanbul ve Çanakkale boğazlarından gelebilecek saldırılara karşı denizlere mayınlar yerleştirilmeli, savaş gemilerinin modern bir hale getirilebilmesi için tersanelerle ilgili yenilikler yapılmalıydı. Ayrıca raporda, modern savaş gemileri satın alınarak bu gemileri kullanabilecek deniz personelin yetiştirilmesinin öneminden de bahsedilmiştir.

\section{Islahatlar için Komisyon Oluşturulması}

Deniz kuvvetlerinin devletin güvenliği için iyi bir seviyeye getirilebilmesi için İstanbul ve Çanakkale boğazlarında bulunan kale ve istihkâmların tamir ve takviye edilmeleri ile sahillere torpido ve mayınlar yerleştirilmesi gibi bazı tedbirlerin alınması gerekiyordu. $\mathrm{Bu}$ tedbirlerin kontrol altında yapılarak tamamlanabilmesi için bir komisyon oluşturulmuştur. İstanbul vapurları süvarisi Şakir Paşa' dan İstanbul ve Çanakkale boğazları istihkâm müfettişi SaffetPaşa ve deniz kuvvetleri hakkında bilgi sahibiüç uzman ileyapılacak sslahatları etraflıca görüştükten sonra neticesini mazbata ile sunması talep edilmiştir. ${ }^{10}$ Ayrıca İstanbul'a gelen Amerikalı bir amiral, deniz mayınlarının Amerika sahillerinde tecrübe edilerek sahillerin güvenliği için savaş gemilerinde de bulundurulmalarını teklif etmiştir. Deniz mayınlarının, uygun sahillere yerleştirilmeleri halinde denizden gelebilecek taarruzlara engel olunabileceği ifade edilmiştir. Ancak, yeni kullanılmaya başlanan torpido vapurlarının, deniz mayınlarını yok etmesi mümkün olabilirdi. Bu nedenle sahillerin muhafazası için deniz mayınları mı ya da başka yollara mı müracaat edilmesi gerektiğinin komisyon tarafından dikkatli bir şekilde araştırılması gerekiyordu. ${ }^{11}$ Torpidolar yerleştirilerek muhafaza altına alınması gereken sahillerin hangileri olduğu, yeni icat edilen dinamit ile torpido atan vapurların özellikleri ile deniz mayınlarının öneminin ortaya konulmasıyla duruma göre tedbirler alınabilirdi. İstanbul ve Çanakkale boğazlarında inşa edilen istihkâmların özellikleri, önemleri ve henüz tamamlanamayanlarında hazır hale getirilmelerinin ardından savunma için yeterli

5 Namık Gökçay, İzmit Tersanesi Marmara Üssü Bahri Marmara Deniz Üs Tarihçeleri (1530-1952), Deniz Basımevi Müdürlüğü, s. 14.

6 Zeki Arıkan, Lütfü Sancar, XVIII. Yüzyll Başından XX. Yüzyll'a Kadar Türk Denizcilik Tarihi 2, İstanbul 2009, s. 91

7 Turhan Şahin, Öncesiyle ve Sonrasiyla 93 Harbi, 1988, s. 79.

$8 \quad$ Ali İhsan Gencer, a.g.e., s. 5.

9 Adnan Şişman, Tanzimat Döneminde Fransa'ya Gönderilen Osmanlı Öğrencileri (1839-1876), Türk Tarih Kurumu, Ankara 2004, s.12.

10 Başbakanlık Osmanlı Arşivi (BOA), Yıldız Perakende Evrakı Yaveran ve Maiyyet-i Seniyye Erkan-1 Harbiye Dairesi (Y.PRK.MYD), 8/50-1-2, 14 Şevval 1306 (12 Haziran 1889).

11 BOA, Y.PRK.MYD, 8/50-1-1. 
olup olmadıklarının incelenmesi gerekiyordu. Bu incelemeler, özel komisyon tarafından ayrıntılı ve dikkatli bir şekilde yapılarak hazırlanan mazbataya göre karar verilebilirdi. ${ }^{12}$ Böylece 1889 senesinde komisyon tarafindan Osmanlı Donanmasında yapılması gereken 1slahatlar için incelemelere başlanmıştır.

\section{Gemilerdeki Islahatlar}

Osmanlı Donanmasındaki gemiler etkileri ve büyüklükleri itibarıyla üç sınıfa ayrılıyordu. Birinci sınıf olarak İstanbul'da inşa edilen donanma gemileri, Mesudiye, Asarı Tevfik, Fethi Bülend, Mukaddime-i Hayr, Avnullah, Muini Zafer firkateyn ve korvetleridir. ${ }^{13}$ Osmaniye, Orhaniye, Mahmudiye ve Aziziye, Selimiye, Ertuğrul, Mehmed Selim firkateynleriyle Asarı Şevket, Necmi Şevket, İclaliye, Hıfzı Rahman, zırhlı korvetleri ikinci sınıf donanma gemileridir. Üçüncü sınıf ise sadece ahşap ve inşaat malzemesinde hem demir hem de ahşap kullanılarak yapılan gambot, sürat vapuru ve nakliye gemilerinden oluşmaktadır. Bunları, Tersane-i Amirelerde inşa edilenlerle İngiltere ve Almanya'dan satın alınacak toplam 27 torpido vapuru ve torpido istimbotları takip etmiştir, seri seyirli vapurlar da üçüncü grup içindedir. ${ }^{14}$ Gemilerden birinci grubu teşkil eden zırhlı firkateyn ve korvetlerin inşa tarihleri olan bundan on yedi, on sekiz sene önce birinci derecede savaş gemilerinden sayılmazlardı, ancak zamanla inşa edilen savaş gemilerinin zırhla kaplanmaları günden güne hızla artmıştı. Ayrıca, zırh levhaları çelik ve demir karışık olarak daha öncekilere nazaran daha dayanıklı olarak imal edilmişti. Gemilerin içlerine Krupp ${ }^{15}$ topları yerleştirildiğinden ağırlıkları artmakla beraber seyirlerindeki hızları da hemen hemen on sekiz mile çıkmıştı. Birinci sınıf donanma gemilerinde yapılan bu ilerlemeler sonucunda ikinci sınıf gemilerde de bazı değişiklikler ve yenilikler yapılması gerekiyordu.

Donanmada yapılması düşünülen 1slahatlara göre; birinci sınıf olarak gösterilen 7 zırhlı korvet ve firkateynin taşıdıkları Armstrong topları büyüklüğündeki topların sayısı ve ağırlıklarına denk Krupp toplarıyla teçhiz edilmelidir. Gemilerin her biri için yeni torpido, sandal ve istimbotlar satın alınmalıdır. İkinci sınıf 4 zırhlı firkateynde ise bazı sslahatlar yapılarak birinci sınıf savaş gemilerinin arasına geçmeleri sağlanabilir. Donanmanın güçlenmesi için birinci sınıf savaş gemilerinin sayısının da artması gerekir. Birinci sınıf donanma gemilerinde yeni inşa edilen zırhlı gemilere benzer bir şekilde değişiklikler ve yenilikler yapılması mümkündür. Gemilere küçük çapta toplar yerleştirilmesi için güverteleri üzerine çelikten üretilen birer tabya ilave edilerek Krupp toplarıla teçhiz olunmalıdır. Donanmada torpido gemilerinin müdafaasında kullanılan Nordenfield topları yeterli sayıda bulunmadığından topların en son usulde imal olunanlardan 100 tane daha satın alınmalıdır. Bunların dışında bir de kazanlarının yenilenmesine çalışılmalıdır. Üçüncü sınıf kabul edilen torpido vapurlarının da mümkün olabildiği kadar sayılarının artırılması gerekir. Savaş gemilerinin sayıları hakkındaki zorunlu sslahatlar ile beraber ele alınması gereken diğer önemli konu ise İngiltere'de en son usule göre yapılmış olan birinci

\footnotetext{
12 BOA, Y.PRK.MYD, 8/50-2-1.

13 BOA, Y.PRK.MYD, 8/50-2-3.

14 BOA, Y.PRK.MYD, 8/50-2-2.

151811 yılında, Friedrich Krupp ilk çelik fabrikasını kurdu. 1856 yılında, oğlu Alfred Krupp 9 cm'lik çelik namludan dolumlu topu üretti. 1863 yılından itibaren, donanmalar için de çelik toplar üretilmeye başlandi.
} 
sınıf zırhlı gemilerin kuvvet ve büyüklügünde 3 zırhlı ile keşif ve takip hizmetlerinde kullanılmak üzere ikisi zırhlı ve diğer ikisi zırhsız olarak 4 tane kruvazör tedarik edilmesidir. Dinamit ile torpido atan vapurlar ise yeni kullanılmaya başladıklarından daha tecrübeleri yapılmamıştır. Bunların etkilerine dair henüz tam bir sonuç elde edilememiş olduğundan, faydaları hakkında şimdilik bir fikir beyan etmek mümkün değildir. Bu konuda Tersane-i Amirede incelemeler yapılarak elde edilen verilere göre karar verilebilir. Bunlar, donanma için yapılması gereken zorunlu islahatlardır ve komşu devletlerin donanmalarından her hangi birisinin saldırılarına engel olabilecek bir seviyeye ulaşılması amaçlanmaktadır.

Donanma tarafindan 1slahat yapılması için bütün zırhlı gemilerdeki Arrmstrong usulündeki topların Krupp usulüne değiştirilmesine karar verilmiştir. Gemilerde yapılan bu değişikliklerden sonra bazı masraflarda ortaya çıkmaktadır. Firkateyne, $15 \mathrm{~cm}$ 'lik 2, 17 cm'lik 2 ve 4 cm'lik 10 Krupp topu yerleştirilecektir. Buna göre, toplam olarak 14 Kurup topu 120 bin 600 liradır. Mesudiye firkateynine yerleştirilecek $24 \mathrm{~cm}$ 'lik 12 top ise 120.600 liradır. Asarı Tevfik firkateyni için $21 \mathrm{~cm}$ 'lik 6 topun bedeli ise 51 bin liradır. Feth-i Bülend, Avnullah, Mukaddeme-i Hayr, Muini Zafer korvetlerine yerleştirilecek $21 \mathrm{~cm}$ 'lik dörder tane top (16 top) 150 bin liradır. Necmi Şevket, İclaliye, Asarı Şevket korvetlerinden her birine yerleştirilecek $21 \mathrm{~cm}$ 'lik dörder tane top (12 top) ise 112 bin 500 liradır. Osmaniye, Orhaniye, Mahmudiye, Aziziye firkateynlerinde bulunan toplar, $26 \mathrm{~cm}$ 'lik bin lira olan Krupp toplarıyla değiştirilecektir. 100 adet Nordenfield topları 40 bin, toplam 64 tane Krupp ve 100 tane Nordenfield topları ise 643 bin 700 liradır. Tersane-i Amirelerde inşa olunan korvetlerin patlayıcı maddeleri için gerekli 50 bin lira da buna ilave edilince donanmada yapılan değişiklikler ve ıslahatlar sırasında satın alınacak Krupp ve Nordenfield patlayıcıları tahmini olarak 693 bin 700 liradır. Osmaniye, Orhaniye, Mahmudiye Aziziye isimlerindeki korvetlerin yüzeylerindeki zırhlarda yapılacak tadilat için 86 bin lira, Tersane-i Amirelerde inşa edilen kompazayt korvetler için de 50 bin lira kadar masraf olmaktadır. ${ }^{16}$

Donanma kuvvetinin iyi dereceye getirilmesinde savaş gemileri satın alınması en önemli konulardan biridir. Donanma için ihtiyaç duyulan gemilerden birinci sınıftan 3 tane zırhlının yeterli silah, mühimmat ve diğer araç-gereçleri ile satın alma bedelinin her biri 900 bin lira olmak üzere toplam 2 milyon 700 bin liradır. 2 zırhlı kruvazör, 600 bin, 2 zırhsız kruvazör ise 300 bin lira olup toplam 3 milyon 600 bin liradır. Buna patlayıcı madde ücreti olan 693 bin 700 lirada ilave edilirse yeniden satın alma bedeli toplam 4 milyon 293 bin 700 lira tutmaktadır. Bunların satın alınmalarından sonra Tersane-i Amirelerde yapılması gereken 86 bin liralık masraf bu hesaba dahil değildir. Bütün masrafın bir defada ödenmesi mümkün olmadı ğından bir kaç sene bahriye bütçesi tahsisatına maliye bütçesinden bir milyon 73 bin 425 lira kadar ek ödeme yapılmalıdır. Ayrıca, bu ıslahatların Tersane-i Amireler tarafından yapılmasını kolaylaştırmak için bahriyenin genel tahsisatından da her sene yeterli miktarda bir ödemenin ilave edilmesine çalışılmalıdır. ${ }^{17} \mathrm{Bu}$ planların uygulamaya geçirilebilmesi için zırhlı korvet ve firkateynlerde değiştirilecek patlayıcıların hemen siparişi verilmelidir. Ayrıca, yeniden tedarik edilmesine ihtiyaç görülen 3 zırhlı firkateyn ile 2 zırhlı, 2 zırhsız 4 kruvazörden öncelikle birinci sınıftan 1 zırhlı ile 2 zırhlı kruvazörün sipariş edilmesinin

16 BOA, Y.PRK.MYD, 8/50-2-4.

17 BOA, Y.PRK.MYD, 8/50-2-4. 
amacın gerçekleşebilmesi için çok önemli olduğu düşünülmektedir. ${ }^{18}$

\section{Donanma için Personel Yetiştirilmesi}

Donanmanın her türlü yaşanabilecek durumlara karşı iyi bir şekilde muhafazası, 1slahatların başarılı olması deniz kuvvetlerinde görevli zabitan ve askerlerin talim ve manevralar yaparak maharet kazanmalarına bağlıdır. Donanmanın kuvveti artırılırken zabitan ve efradın, bu gemileri her durumda iyi bir şekilde idare edebilmeleri için doğrudan eğitim almaları şarttır. Talim gemilerinde verilen eğitimle zabit ve efradın hem gemilerin hareketlerini ve işleyişini tam olarak öğrenmeleri hem de Osmanlı Devleti ile yabancı devletlere ait sahil ve limanlarda seyir halindeki gemi makinelerinin işleyişi hakkında bilgi sahibi olabilmeleri amaçlanmaktadır. Gemilerden silah atışları yaptırılmalı, bu atışların süratleriyle belli bir mesafeyi kat edip edemediklerine dikkat edilmelidir. Donanmada yapılan ıslahatların başarılı olması için talim gemilerine ilaveten bahriye zabitanı ve efradının talimi için küçük yelkenli gemiler de kullanılmalıdır. Zabitan ve efrad bu gemilerde başarılı talimler yaparak ileride büyük gemilerde güvenli bir şekilde görevlerini yerine getirebilirler. $\mathrm{Bu}$ gemilerde zabitan ve efrad, talim mevsimlerinde devamlı görevleri ile meşgul olabilir. Zabitan ve efradın donanmayı oluşturan savaş gemilerini iyi bir şekilde ustalıkla idare etmeye hazırlamış olmaları dikkat edilmesi gereken konulardandır. Donanmada başlayan 1slahat hareketlerine göre küçük zabitan olarak ateşçi, ser topçu, ser dümen ve porsunluk hizmetleri adında bahriye gedikli sınıfları da açılmalıdır. Bahriye efradı, kısa süre içinde görevlerinden ayrıldıklarından yeterli sayıda olmamaktadır. Efrad sınıfının düzenli bir hale getirilmesi ve sürekli hizmette bulunmalarını sağlayacak bir nizamnamenin Tersane-i Amirelerde hemen hazırlanıp uygulanması gerekir. Donanma personeli yetiştirilirse deniz kuvvetlerinin hem inşaat araç-gereçleri ile teçhizatı hem de gemileri ile birkaç sene zarfında İstanbul ve Çanakkale boğazlarını muhafaza edebilecek ve düşman devletlerin donanmalarının taarruzuna engel olunabilecektir.

\section{Boğazlardaki İstihkâmların Tahkim Edilmeleri}

Osmanlı topraklarının her türlü duruma karşı muhafaza ve müdafaasının sağlanması için Çanakkale boğazının uygun bir şekilde tahkim edilmesi gerekir. Bu konuda oluşturulan komisyonların yaptıkları incelemeler sonucunda bazı konulara riayet ederek tahkimat yapılmış ve Çanakkale boğazının müdafaasının dört hat şeklinde olmasına karar verilmiştir. Bu tahkimatın boğazın Akdeniz'e doğru olan girişinde bulunan Seddülbahir ile Kumkale arasinda birinci hat, Kepez ve Kumburnu noktaları arası ikinci hat, Hamidiye, Namazgâh, Çimenlik, Mecidiye istihkâmlarıyla eski Mecidiye ve Değirmenburnu üçüncü hat, Bigali ve Nara burnu noktaları arası da dördüncü hat olmak üzere belirlenmiştir. $\mathrm{Bu}$ istihkâmlardan bazılarının gerilerinde bulunan uygun mevkilere de yüksek bataryaların inşasına başlanmıştır. Bu inşaatın durumuna gelince;

Birinci müdafaa hattını teşkil eden Seddülbahir, Kumkale, Ertuğrul ve Orhaniye isimlerindeki dört adet istihkâm tamamlanıp içlerine uygun çaplarda $20 \mathrm{Krupp}$ topu yerleştirilmiştir. İkinci müdafaa hattına henüz istihkâmlar inşa edilmemiştir. Üçüncü müdafaa hattında istihkâmlar; Namazgâh, Hamidiye, Yeni Mecidiye, Çimenlik tabyaları 
tamamlanarak içlerine muhtelif çapta toplam 63 top, 4 havan yerleştirilmiştir. Dördüncü müdafaa istihkam hattını teşkil eden Rumeli sahilinde Bigali ile Anadolu sahilinde Naraburnudur. Naraburnu daha önceden mevcut olup muhtelif çapta 10 topu içine alabilmektedir.

Boğaz savunma hududunu teşkil eden istihkâmların arkalarındaki bataryalardan dahi Rumeli taraflarında Tekeburnu, Goncasuyu (Palaz baba), Çamburnu, Çakıllı Tepe isimlerindeki tepelerde bulunan istihkâmlar tamamlanıp toplam 18 top ve 6 havan topu yerleştirilmiştir. Anadolu yönünde Maltepe Bataryası inşa edilip 6 top ile 2 havan topu ile teçhiz olunmuştur.

Çanakkale boğazının tahkim edilmesi, istihkâm müfettişliği tarafından arz edilmiş, bu durum komisyon tarafından incelendikten sonra layiha hazırlanmıştır. Bu layihada, eski toplardan bazılarının kaldırılması, siperlerin değişimi ve ıslah edilmeleri teklif edilmiştir. Buna göre; birinci müdafaa hattını teşkil eden Seddülbahir ve Kumkale ile birlikte içine 2 top yerleştirilmek üzere Orhaniye istihkâmı da ilave edilerek genişletilmelidir. İkinci müdafaa hattını teşkil eden Kepez ve Kumburnu istihkâmları, karara göre dörder top yerleştirilecek surette inşa edilmelidir. Ayrıca her iki istihkâmın arkasındaki uygun noktalara 10 havan topu yerleştirilmesi zorunludur. Üçüncü müdafaa hattı istihkâmlarından Namazgâh istihkâmında bulunan eski toplar kaldırılmalı, yerlerine $35 \mathrm{~cm}$ 'lik top yerleştirilebilecek şekilde tadilat yapılmalıdır. Komisyona göre; Namazgâh istihkâmının bulunduğu üçüncü müdafaa hattı, boğazın en önemli savunma hattını teşkil edip her konuda büyük bir önem taşımaktadır. Bu noktanın harita üzerinden incelenmesi doğal olarak mümkün değildir. Ayrıca, 2 topun Namazgâh istihkâmına mı veya başka bir istihkâma mı yerleştirileceği belirli değildir. Toplar için ondan fazla uygun mevkii olduğundan bu konunun keşif yapılarak belirlenmesi uygun bulunmuştur. Dördüncü istihkâm hattından Bigali istihkâmının inşa edilmesi müdafaanın sorunsuz olmasi için zorunludur. ${ }^{19}$

Boğazın müdafaası için kullanılan istihkâmlardan Anadolu taraflarında Nara, Eski Mecidiye Çimenlik ve Rumeli'de ise Değirmenburnu ve Namazgâh istihkâmları çok önce inşa edildiklerinden ve inşalarından bir hayli zaman geçtiğinden tamire muhtaç bir durumdadırlar. Bunların cephanelikleri rutubetli bir durumda olduğu gibi ayrıca tamir ve bakımlarının yapılması gerekir. Bu düzenlemelerin yanında Nara istihkâmının siperlerinin artırılmasına da çalışılmalıdır. Eski Mecidiye ve Namazgâh istihkâmlarının topları ise çok sıkı bir şekilde yerleştirildiğinden dolayı cephaneliklerin güvenliği için tehlikeli bir durum vardır. Bu nedenle konunun sınır karakollarına bildirilerek toplardan bir miktarı uygun yerlere kaldırılmalıdır. Boğazın müdafaası için birinci, ikinci ve dördüncü hatlara üçer ve üçüncü hatta ise beşer sira olmak üzere 4 hat şeklinde torpido yerleştirilerek müdafaası güçlendirilmelidir. Çanakkale boğazında mevcut bulunan torpidoların iyi bir şekilde muhafazalarına çalışılmalıdır. İkinci müdafaa hattına doğru ilerlemek isteyecek düşman donanmasını engellemek için Kepez limanının demir mahallerine torpidolar yerleştirilmelidir. Ayrıca torpido taşınmasına mahsus olan vapurlardan gerek İstanbul ve gerekse Çanakkale boğazı için birer tane satın alınmalıdır. Burada ayrıntılı bir şekilde anlatılan kararların tamamen yapılması ve tamamlanması halinde Çanakkale boğazına 
doğrudan yapılabilecek bir donanma taarruzuna karşı güvenlik sağlanmış olabilir. Sahil müdafaası tahkim edilmiş olunursa Gelibolu'dan karaya asker çıkarılması da mümkün değildir. Bu nedenle kuzeyden bir taarruz durumuna karşı şubenin tahkim edilerek boğaza arkadan saldırılmasını engelleyecek tedbirlerin alınmasına önem verilmelidir. Bolayır'da öncelikle yapılmasına karar verilen istihkâmların inşaat ve teçhizatı hemen tamamlanmalıdır. Boğazın gerek sahilde ve gerekse Gelibolu'da inşasına karar verilen istihkâmlarının tamamlanmasından sonra boğaz girişinden ve Akdeniz üzerinden yapılabilecek taarruzlara engel olunabilir. .

İstanbul boğazı hakkında oluşturulan komisyonların kontrolü altındaki istihkâmlar, üç savunma hattı şeklinde düzenlenmiştir. Birinci hattın, Poyraz, ikincisinin Büyük liman ve Fil Burnu koyu, üçüncüsünün ise Rumeli ve Anadolu kavaklarında bulundurulması karar verilmiştir. Bu istihkâmlara da üçer sıra torpido yerleştirilmesi uygun bulunmuştur. Ayrıca, üçüncü hattın Anadolu kavağına doğru yüksek noktalarına havan ve top tabyaları, daha önceden yapılmış olan Mesar burnu tabyasıyla inşasına başlanan Kireç burnu ve Rumeli kavağının üst tarafında sahil istihkâmının dahi üçüncü müdafaa hattı istihkâmlarında düzenlemeler yapılmalıdır. İstanbul Boğazı'ndaki istihkâmların da hızlı bir şekilde inşaları tamamlanmalidir.

İstanbul Boğazı hakkında alınması gereken zorunlu tedbirlere gelince; boğaz istihkâmlarından henüz inşa edilmemiş olanların hemen inşalarına başlanmalıdır. Boğazın mevcut istihkâmlarının en önemli noktaları deniz yüzeyinden 8 ile 10 metre yükseklikten az olmamalıdır. Bununla beraber boğazın ağızına iki adet elektrik feneri yerleştirilerek gece vakti tarassud durumuna hazırlanmalıdır. Boğazın dışında bulunan fener dubasıyla sahil arasına denizaltı bir telgraf hattı yerleştirilmelidir. Üçüncü hudut için yerleştirilecek torpidoların yerleri, mevkileri, her birinin numarası ile her bir araç ve gereçleri şimdiden tedarik edilmelidir. Bunlar için depolar, seyyar torpido saldırılarına karşı boğazın güvenli ve uygun yerlerine inşa edilmelidir. Ayrıca, depoların inşasında kullanılacak alet, araç ve gereçlerin hemen tedarik edilmesi gerekir. Boğazda sahil istihkâmlarının 16 ile 19 metre yükseklikte bulunan mevzilere inşa edilmesine de önem verilmelidir. ${ }^{20}$

\section{Boğazlara Torpidolar Yerleştirilmesi}

İstanbul ve Çanakkale Boğazlarının sahil istihkâmları ile denize yerleştirilecek torpidolar hakkında yeterli güce sahip bir donanma olmalıdır. Bu tahkim ve müdafaalar, boğazlardan meydana gelebilecek taarruzlara karşı zorunlu tedbirlerdir. Boğazlar dışında ki sahillerin de ihtiyaca göre tarassud ve müdafaalarında çevrelerinde bulunan askeri kuvvetler görevlendirilmiştir. Bu kuvvetlerin barış zamanın da düzenlenerek hızlı bir şekilde boğaza sevk edilmeleri için gerekli tedbirler alınmalıdır. Bolayır istihkâmlarının tamamı ve her iki boğazın girişleri dışına asker dökülmesini engellemek amacıyla istihkâm topçu efradı daima sınırda tutulmalıdır. Boğazlara düşünülebilen saldırılara karşı kuvvetli bir şekilde hareket edebilmek için her iki boğaz istihkâmlarında topçu askerleri, barış zamanında dahi belirli sayıda bulundurulmalıdır. Boğazların girişleri dışındaki Rumeli ve Anadolu sahilindeki askeri mevkilerin birbirlerine telgraf hatlarıyla bağlanması gerekir. İstanbul boğazı ağzında karakol gemisi bulundurulmasına çalışılmalıdır. Birde boğazlar, 
sadece sahil istihkâmlarında denize yerleştirilen torpidolarla tahkim edilmeyip müdafaanın bir kat daha sağlam olması için ihtiyaç durumunda yeterli sayıda savaş gemisi ile birlikte torpido istimbotları da savunma için hazır olmalıdır. Bu layihada donanmanın sslah edilerek kuvvetin artırılması hakkında arz edilen konular, amacın teminini kolaylaştıracak maddelerden oluşmaktadır. Birde İstanbul ve Çanakkale boğazlarına konu olan torpidoların yerleştirilmesi ve çıkarılmasında kullanılmak üzere iki vapur satın alınmasına çalışılmalıdır. Yukarıda açıklandığı üzere Çanakkale boğazı girişi dışından Girit’ten başka Akdeniz'de bazı uygun noktaların tahkimi, boğaz hudut istihkâmının inşaatının tamamlanmasına bağlı olduğundan bunlar hazırlanmadıkça adalarda istihkâm yapılmamasına dikkat edilmelidir. Çanakkale'de bulunan Nordenfield ve mitralyözlerin düşman gemilerinden muhafazaları için üzerlerine koruyucular yerleştirilmelidir. ${ }^{21}$

Osmanlı Devleti'nde sahillerin mayınlarla muhafazası konusuna gelince; boğaz, nehir veya liman girişlerinin denizaltı mayınları ile sed çekilerek tahkim edilmesi Türk topraklarının muhafazası için çok önemli bir konudur. Bu nedenle denizden gelebilecek saldırılara karşı mayınlarla ilgili yenilikler ve değişiklikler yapılmaktadır. Mayınlarla Türk sahillerinin koruma altına alınması gerektiğini 1877-1878 Osmanlı-Rus Savaş1 kanıtlamıştır. Karadeniz sahili boyunca Rus saldırılarına karşı mayınlarla hazırlık yapılmış olsaydı, savaş sonunda çok az toprak kaybı olabilirdi. Bu amaçla mayınların yerlerinin belirlenmesi, planlarının yapılması, muhafazaları hakkında incelemeler yapılmalıdır. Akdeniz'de Trablusgarp sahili, Beyrut, Akka, İzmir, Beşik, Dedeağaç, Selanik, Preveze ve Suda, Karadeniz sahilinde Sinop, Trabzon, Çatalca, Terkos ve Kilos civarı, Bahri Ahmer sahilinde Cidde, Basra körfezinde bulunan boğazlar gibi müstahkem askeri mevkilere uygun torpidolar yerleştirilerek muhafazaları sağlanabilir. Sadece, bazı sahillerde uygun yerlere yerleştirilen mayınlar, deniz altında yerleştirildikleri yerlerde durmayarak denizde serseri hale gelmektedir. Sahillerde güvenliğin tam olarak sağlanabilmesi için bu konuya da dikkat edilmelidir. ${ }^{22}$

Islahat komisyonunun raporuna göre; donanmanın ıslah edilerek iyi bir seviyeye getirilebilmesi için sahillere torpidolar yerleştirilerek muhafazaları sağlanmalı, İstanbul ve Çanakkale boğazlarında istihkâmların tamir ve tahkimatları yapılarak torpido vapurları kullanılmaya başlanmalıdır. Bu rapora göre hareket edilebilirse devletin güçlü bir hale gelebileceği düşünülmektedir. ${ }^{23}$ (12 Haziran 1889)

\section{Sonuç}

Yenilik anlamına gelen 1slahat, 18. Yüzyılın ikinci yarısından itibaren ve özellikle 19. Yüzyılda Osmanlı Devleti tarafindan Avrupa ön planda tutularak yapılmaya çalışılmıştır. Osmanlı Donanmasından yapılan sslahat hareketlerinde denizlerde yaşanan büyük felaketler oldukça etkili olmuştur. Özellikle, 1877-1878 Osmanlı Rus Savaşı ile yaşanan büyük kayıplar sonucunda donanmanın zayıf bir durumda olduğu fark edilmiştir. Aynı zamanda gemileri bilinçli bir şekilde yönetecek, kullanabilecek iyi öğrenim ve eğitim görmüş personele de ihtiyaç olduğu gözden kaçırılmamıştır. Osmanlı Donanmasının ıslah

\footnotetext{
21 BOA, Y.PRK.MYD, 8/50-3-2.

22 BOA, Y.PRK.MYD, 8/50-2-6.

23 BOA, Y.PRK.MYD, 8/50-3-1, 14 Şevval 1306 (13 Haziran 1889).
} 
edilebilmesi için uzmanlardan yararlanma yoluna gidilerek bir komisyon oluşturulmuştur. $\mathrm{Bu}$ komisyon tarafından deniz kuvvetlerinin güçlendirilmesine dair incelemeler yapılarak sslahatlar hakkında bir rapor hazırlanmıștır. Komisyonun raporuna göre, donanma tarafından yapılması zorunlu görünen 1slahatların uygulamaya geçirilmesi sonucunda deniz gücünün iyi bir seviyeye getirilmesi mümkün olabilirdi. Osmanlı Donanmasında komisyonun raporu ile yeni zırhlı gemiler satın alınmaya başlamıştır. Ayrıca, boğazlarda güvenliğini sağlanabilmesi için bir plan doğrultusunda deniz mayınları yerleştirilmiştir. Boğazlara yerleştirilen bu mayınlar, Çanakkale Cephesinde yaşanan deniz savaşlarının kazanılmasında çok büyük bir rol oynamıştır. Osmanlı Donanması için hazırlanan ıslahat planları, mayınlar kadar denizcilerin yetiştirilmesi için açılan okullar, torpidolar ve Krupp topları gibi birçok noktada uygulamaya geçirilmiştir.

\section{Kaynakça}

\section{Arşiv Belgeleri}

\section{Başbakanlık Osmanlı Arşivi (BOA)}

Yıldız Perakende Evrakı Yaveran ve Maiyyet-i Seniyye Erkan-1 Harbiye Dairesi (Y.PRK.MYD), 8/50-1-1, 8/50-1-2, 8/50-2-1, 8/50-2-2, 8/50-2-3, 8/50-2-4, 8/50-2-5, 8/502-6, 8/50-2-7, 8/50-2-8, 8/50-3-1, 8/50-3-2.

\section{Diğer Kaynaklar}

Gülen, Nejat. Şanlı Bahriye Türk Bahriyesinin İki Yüz Yıllık Tarihçesi 1773-1973. İstanbul: 2001.

Türk Deniz Harp Tarihinde İz Bırakan Gemiler, Olaylar ve Şahıslar, Çeşme, Navarin, Sinop Baskınları ve Sonuçları, İstanbul: Piri Reis Araştırma Merkezi, 2007.

Gencer, Ali İhsan. Türk Denizcilik Tarihi Araştırmaları. 1 Basım. İstanbul: Türkiye Denizciler Sendikası Eğitim Dizisi 2, 1986.

Şahin, Turhan. Öncesiyle ve Sonrasiyla 93 Harbi. 1988.

Armaoğlu, Fahir. 19.Yüzyıl Siyasi Tarih (1789-1914). Ankara: Türk Tarih Kurumu Yayınlar1, 1997.

Şişman, Adnan. Tanzimat Döneminde Fransa'ya Gönderilen Osmanlı Öğrencileri (1839-1876). Ankara: Türk Tarih Kurumu, 2004.

Gökçay, Namık. İzmit Tersanesi Marmara Üssü Bahri Marmara Deniz Üs Tarihçeleri (1530-1952). Deniz Basımevi Müdürlügüü.

Özcan, Besim. Sinop Deniz Felaketi, 30 Kasım 1853, İstanbul: 2008.

Arıkan, Zeki; Sancar, Lütfü, Türk Denizcilik Tarihi Cilt. 2, İstanbul: 2009. 
Tarih ve Gelecek Dergisi, Haziran 2020, Cilt 6, Sayl 2

280 Journal of History and Future, June 2020, Volume 6, Issue 2

\section{EK 1. Gemi Planı}

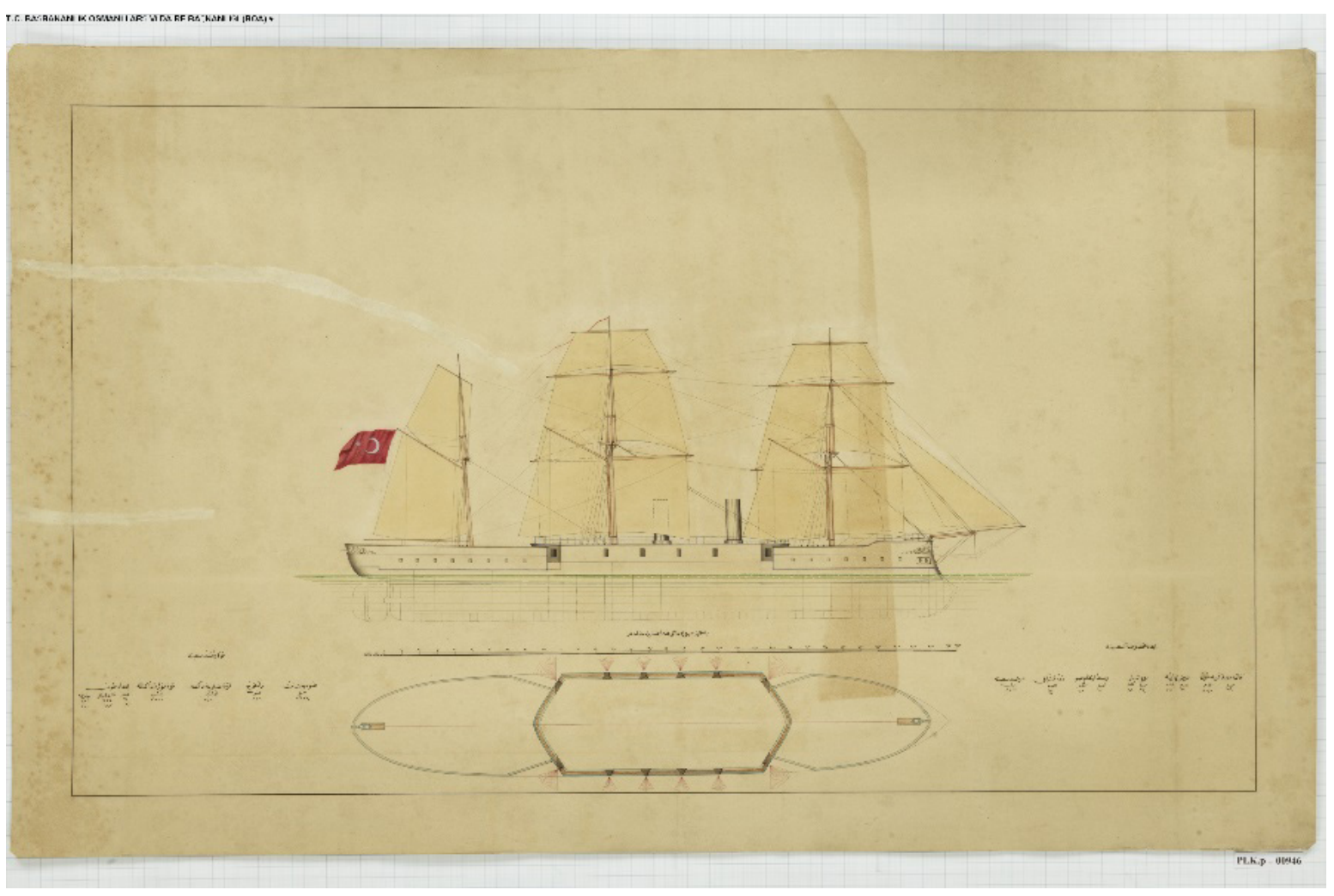

